$\xi=1$ 国

\title{
Health Risks Assessment of Rainwater Pollutants in Jengka, Pahang, Malaysia
}

\author{
Siti Nadzifah Ghazali ${ }^{1,2 *}$, Fazrul Razman Sulaiman ${ }^{2}$, Mohd Zahari Abdullah ${ }^{2}$ \\ ${ }^{I}$ Faculty of Applied Sciences, Universiti Teknologi MARA Shah Alam, Malaysia \\ ${ }^{2}$ Faculty of Applied Sciences, Universiti Teknologi MARA Cawangan Pahang, Malaysia \\ *Corresponding author E-mail: nadzifahghazali@yahoo.com
}

\begin{abstract}
Rainwater samples were collected in Jengka, Pahang Malaysia. Temperature, $\mathrm{pH}$, TDS, EC, $\mathrm{Al}, \mathrm{Cu}, \mathrm{Mn}$, and $\mathrm{Zn}$ were measured. The concentrations of heavy metals $(\mathrm{Al}, \mathrm{Cu}, \mathrm{Mn}$ and $\mathrm{Zn})$ in thirty-eight samples were analysed using inductively coupled plasma-mass spectrometry (ICP-MS). Statistical analysis results indicate that $\mathrm{pH}$, TDS, and EC showed significant differences between wet and dry seasons. However, no significant difference was observed seasonally for heavy metals (HMs). All parameters, except pH, were below the Malaysian Drinking Water Guidelines (MDWG) value and the health risk assessment for HMs indicates the safe levels. Principal component analysis (PCA) suggests that HMs in rainwater in Jengka, Pahang were originated from natural and anthropogenic sources.
\end{abstract}

Keywords: Aluminium; Copper; Manganese; PCA; Stormwater; Zinc

\section{Introduction}

Development and human activities generate a various type of pollutant loads. Among the various pollutants, chemical pollutants such as heavy metals (HMs) has been a concerning issue over decades because of their toxicity for animal, plant and human beings (1). The assessment of HMs in rainwater attracts great attention as HMs could pose serious health risks to the human population and contribute to surface water pollution. Rainwater could be collected for potable and non-potable usage and there is a risk of the exposure of HMs in rainwater through the oral intake and dermal contact.

Risk assessment proposed by United States Environmental Protection Agency (USEPA) has proved successful in determining the water safety level and has been adopted worldwide (2). There are two types of the environmental risk assessment which are a healthbased risk and ecological risk assessments. The presence of HMs in rainwater could lead to non-carcinogenic and carcinogenic health effects on a human that in contact with rainwater. Some HMs could give significant adverse health effects. For example, $\mathrm{Cu}$ and $\mathrm{Zn}$ are known as essential metals for the human body. However, an excessive intake of $\mathrm{Cu}$ and $\mathrm{Zn}$ results in vomiting, nausea and can contribute to organs damage (3). The accumulation of $\mathrm{Al}$ in the human body can damage the nervous systems (4-5). Hazard index (HI) is commonly used in calculating the risk posed by HMs in water. Although HI does not provide an indication of the cancer effects from rainwater exposure, it does provide an indication of the risk level to an individual that exposed to rainwater. HI has commonly been used in recent environmental studies [6-8] and has been shown to be valid and useful. HI generally increases with the increase of rainwater pollutants. The contamination of rainwater is likely related to human activities. For example, a comparative study of rainwater quality in the rural and urban area shows that the level of rainwater contamination in an urban area is much higher than in a rural area, in which the level of rainwater contamination is related to human activities (9). Therefore, it is important to identify the pollutant sources and to ensure the concentrations of HMs in rainwater were within the water safety levels. This study aims to assess the health risk posed by HMs in rainwater. The seasonal variation and source of pollutants that influenced HMs in rainwater and $\mathrm{HI}$ were assessed.

\section{Methodology}

\subsection{Sampling and Analysis}

A total of thirty-eight rainwater samples were collected in Universiti Teknologi MARA (UiTM) Cawangan Pahang, Jengka Campus, Pahang Malaysia. The sampling area located in a suburban area in the middle east region of Pahang, Malaysia. There is a wood factory as well as construction activity within the university area. Therefore, this study was done to investigate whether human activities affect the rainwater quality and subsequently assess the health risk assessment for individual adults that in contact with rainwater.

The sampling activities were carried out in wet and dry seasons to monitor the quality of rainwater and changes caused by the season. The wet season is related to Northeast Monsoon which occurs in between November to February. The dry season takes place during Southwest Monsoon which is from March to August. The samples were collected using pre-wash polyethylene container to avoid unpredicted dissolved heavy metals from the sampling container. The collected rainwater was directly transported to the laboratory for physicochemical analysis, namely: temperature, $\mathrm{pH}$, total dissolved solids (TDS), and electroconductivity (EC). The physicochemical parameters were measured using YSI 600. The concentrations of heavy metals ( $\mathrm{Al}, \mathrm{Mn}, \mathrm{Cu}$, and $\mathrm{Zn}$ ) were analysed using Inductively coupled plasma-mass spectrometry (ICP-MS). 


\subsection{Statistical Analyses}

All statistical analysis for rainwater pollution assessment was carried out in Statistical Package for the Social Sciences (SPSS 21). T-test analysis with significance level set at $p<0.05$ was used to calculate the average of HMs in each season and to distinguish the significant difference between wet and dry seasons. Principal component analysis (PCA) with varimax rotation with Kaiser Normalization was performed to assess the possible sources of HMs in rainwater. A maximum variance and a pattern of loadings for each factor can be obtained through the applied method.

\subsection{Health Risk Assessment}

Exposure assessment involves an assessment of the exposure of HMs in rainwater to human which are through the oral intake and dermal contact. Oral intake is separated into two which are water ingestion as drinking water and incidental ingest water while swimming (2). For this study, water ingestion as drinking water and dermal contact was considered for the exposure assessment. The chronic daily intake for individual adult ingestion of rainwater as drinking water and dermal contact were calculated based on equation (1) and (2), respectively.

$\mathrm{CDw}_{\mathrm{i}}=\mathrm{C} \times \mathrm{IRw} \times \mathrm{EF} \times \mathrm{ED}$

BW x 365 DAYS/YEAR x AT

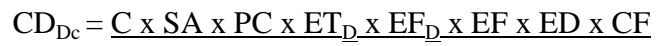

BW x 365 DAYS/YEAR x AT

Definition 2.1: Where $C$ is the HMs concentration in rainwater $(\mu \mathrm{g} / \mathrm{L}), I R$ is water ingestion rate (2 L/day), EF is the exposure frequency (365 days/year), ED is the exposure duration (30 years), SA is skin surface area available for contact (1800 cm2), $P C$ are chemical-specific dermal permeability constant $(0.7$ $\mathrm{cm} /$ hour $), E T_{D}$ (2.6 hours/event) and $E F_{D}$ (7 events/year) are exposure time and exposure frequency for swimming, respectively. $C F$ is a volumetric conversion of water (1L /1000 cm3), BW is body weight $(70 \mathrm{~kg})$ and $A T$ is averaging time during exposure to drinking water ( 70 years).

$\mathrm{Al}, \mathrm{Cu}, \mathrm{Mn}$ and $\mathrm{Zn}$ in this study were identified as noncarcinogenic HMs. Therefore, the reference dose (RfD) of each HMs through rainwater ingestion as drinking water and dermal contact was obtained from the Integrated Risk Information System (IRIS) database by USEPA [10]. The RfD for the selected HMs is presented in Table 1 .

Table 1: Reference dose (RfD) of each HMs through rainwater ingestion as drinking water and dermal contact

\begin{tabular}{|c|c|c|}
\hline $\mathrm{HMs}$ & RfDingestion $\left[(\mu \mathrm{g} / \mathrm{kg} . \mathrm{day})^{-1}\right]$ & RfDdermal $\left.^{-1}(\mu \mathrm{g} / \mathrm{kg} \text {.day })^{-1}\right]$ \\
\hline $\mathrm{Al}$ & 1000 & 100 \\
\hline $\mathrm{Cu}$ & 40 & 12 \\
\hline $\mathrm{Mn}$ & 20 & 1.84 \\
\hline $\mathrm{Zn}$ & 300 & 60 \\
\hline
\end{tabular}

The risk for a corresponding HMs on human health can be accessed through hazard quotient (HQ). HQ for water ingestion and dermal contact were calculated using equation (3) and (4), respectively (2).

$\mathrm{HQ}_{\mathrm{Wi}}=\mathrm{CDI}_{\mathrm{Wi}} / \mathrm{RfD}_{\mathrm{Wi}}$

$\mathrm{HQ}_{\mathrm{Dc}}=\mathrm{CDI}_{\mathrm{Dc}} / \mathrm{RfD}_{\mathrm{Dc}}$

Definition 2.2: $H Q_{W i}$ and $H Q_{D c}$ are hazard quotient for heavy metal through water ingestion and dermal contact, respectively (unitless). $C D I_{W i}$ and $C D I_{D c}$ are chronic daily intake by an individual adult through water ingestion and dermal contact, respectively $\left(\mu \mathrm{g} / \mathrm{kg}\right.$. day). $R f D_{W i}$ and $R f D_{D c}$ are reference dose for water ingestion and dermal contact, respectively ( $\mu \mathrm{g} / \mathrm{kg}$.day). $C D I_{W i}$ and $C D I_{D c}$ were obtained from exposure assessment.

In the case where the hazard quotient is less than unity $(\mathrm{HQ}<1)$, it indicates that no concern of adverse health effect for an individual that expose to the corresponding HMs in rainwater during their lifetime. HMs would have potential to affect human health if the hazard quotient greater than unity (HQ>1) $(2,4,5)$.

Hazard index (HI) was used to determine the overall potential for non-carcinogenic effects caused by more than one HMs. HI can be generated by summation of hazard quotient (HQ). Therefore, HI was calculated using equation (5).

$\mathrm{HI}=\Sigma \mathrm{HQ}_{\mathrm{Wi}_{\mathrm{i}}}+\Sigma \mathrm{HQ}_{\mathrm{Dc}}$

Similar to HQ, HI that less than unity $(\mathrm{HI}<1)$ indicates no concern of adverse health effect for an individual that expose to the corresponding HMs in rainwater during their lifetime. The hazard risk greater than unity $(\mathrm{HI}>1)$ indicates that $\mathrm{HMs}$ would have potential non-carcinogenic effect to human health $(4,5,10)$.

The sum of HI $\left(\sum \mathrm{HI}\right)$ for each season was then calculated to evaluate the combined risks for multiple HMs through various exposure pathways in each season. The calculation for $\sum \mathrm{HI}$ was based on the Equation (6).

$\Sigma \mathrm{HI}=\left[(\mathrm{HI})_{\mathrm{Al}}+(\mathrm{HI})_{\mathrm{Cu}}+(\mathrm{HI})_{\mathrm{Mn}}+(\mathrm{HI})_{\mathrm{Zn}}\right]$

\section{Results and Discussion}

\subsection{Heavy Metals in Rainwater}

The composition of HMs in Jengka Pahang Malaysia was characterized by using 38 collected rainwater samples. Table 2 presents the average physicochemical and HMs concentrations in wet and dry seasons in Jengka. The temperatures of rainwater in wet and dry seasons were 25.23 and 26.69, respectively. Statistical analysis results indicate that there were no significant differences in rainwater temperature between the seasons. Therefore, the effect of the temperature on the rainwater pollution will not be further elaborated in this study due to the no apparent trend on the effect of the rainwater temperature between the seasons.

Besides temperature, $\mathrm{pH}$ value is known as another factor that affects the quality of rainwater as the $\mathrm{pH}$ value governs the solubility and biological accessibility of nutrients and HMs in the rainwater. Statistical analysis results indicate that there were significant differences in $\mathrm{pH}$ of rainwater between the seasons. The measured rainwater $\mathrm{pH}$ in this study was slightly higher in the dry season (6.72) compared to the wet season (6.39). Consequently, rainwater in this study area might have the ability to dissolve HMs when the rainfall in contact with the surface such as roof, road or ground due to the rainwater that has $\mathrm{pH}$ value less than $\mathrm{pH} 7$ tends to be corrosive (11).

Total dissolved solids (TDS) and the electrical conductivity (EC) is generally linearly related, the overall quantity of dissolved ions in the water can be estimated by referring to conductivity value. High EC value indicates high dissolved solid content in water (12) In the dry season, total dissolved solids (TDS) and the electrical conductivity (EC) values were $7.6 \mathrm{mg} / \mathrm{L}$ and $0.014 \mathrm{mS} / \mathrm{cm}$, respectively. In wet seasons, TDS and EC values drop to $3.07 \mathrm{mg} / \mathrm{L}$ and $0.003 \mathrm{mS} / \mathrm{cm}$, respectively. Based on T-test output, TDS and EC vary significantly between the seasons with a p-value less than 0.05 .

All HMs in terms of seasonal variation showed no significant difference between the seasons. It is noted of $\mathrm{Al}$ and $\mathrm{Mn}$ more concentrated in dry season compared to the wet season, while the concentration of $\mathrm{Cu}$ and $\mathrm{Zn}$ in rainwater were vice versa. The evaluated concentration of $\mathrm{Cu}$ and $\mathrm{Zn}$ in the wet season might be linked with the use of copper sulphate/chloride and zinc sulphate/chloride in wood industry as one of the wood preservatives and fungi-killing chemical (14-15).

Table 2: Summary of basic statistic of rainwater pollutant. SD is referring to standard deviation and $p$-value, $p<0.05$

\begin{tabular}{|c|c|c|c|}
\hline Parameter & Statistics & Wet season & Dry season \\
\cline { 3 - 4 } & & $(\mathrm{n}=18)$ & $(\mathrm{n}=18)$ \\
\hline Temperature & Mean & 25.23 & 25.69 \\
\hline$\left({ }^{\circ} \mathrm{C}\right)$ & SD & 1.41 & 1.61 \\
\hline
\end{tabular}




\begin{tabular}{|c|c|c|c|}
\hline & $\mathrm{p}$-value & 0.41 & \\
\hline $\mathrm{pH}$ & Mean & 6.39 & 6.72 \\
\hline & SD & 0.44 & 0.31 \\
\hline & $\mathrm{p}$-value & 0.02 & \\
\hline $\mathrm{TDS}$ & Mean & 3.07 & 7.60 \\
\hline$(\mathrm{mg} / \mathrm{L})$ & SD & 2.27 & 6.81 \\
\hline & $\mathrm{p}$-value & 0.02 & \\
\hline $\mathrm{EC}$ & Mean & 0.003 & 0.014 \\
\hline$(\mathrm{mS} / \mathrm{cm})$ & SD & 0.002 & 0.011 \\
\hline & $\mathrm{p}$-value & 0.01 & \\
\hline $\mathrm{Al}$ & Mean & 10.97 & 11.29 \\
\hline$(\mu \mathrm{g} / \mathrm{L})$ & SD & 7.21 & 7.21 \\
\hline & $\mathrm{p}$-value & 0.90 & \\
\hline $\mathrm{Cu}$ & Mean & 2.73 & 1.22 \\
\hline$(\mu \mathrm{g} / \mathrm{L})$ & SD & 2.24 & 0.71 \\
\hline & $\mathrm{p}$-value & 0.18 & \\
\hline $\mathrm{Mn}$ & Mean & 1.53 & 3.50 \\
\hline$(\mu \mathrm{g} / \mathrm{L})$ & SD & 0.98 & 3.05 \\
\hline & $\mathrm{p}$-value & 0.07 & \\
\hline $\mathrm{Zn}$ & Mean & 14.61 & 8.57 \\
\hline$(\mu \mathrm{g} / \mathrm{L})$ & SD & 10.95 & 7.18 \\
\hline & $\mathrm{p}$-value & 0.22 & \\
\hline & & & \\
\hline
\end{tabular}

Malaysian Drinking Water Guidelines (MDWG) by Malaysian Ministry of Health (MMOH) (15) were used to determine whether the collected rainwater in this study was safe to be used as a drinking water or vice versa. Table 3 shows that TDS and all HMs were within the recommended values. Only $\mathrm{pH}$ value in wet season was slightly below the MDWG value. Even though the $\mathrm{pH}$ value in the wet season (6.4) was below the minimum recommended $\mathrm{pH}$ value (6.5), the collected rainwater was considered safe to be consumed because only $\mathrm{pH}$ value of drinking water that are less than four $(\mathrm{pH}<4)$ or that greater than eleven $(\mathrm{pH}>11)$ can give harmful effect on the consumer (17-18).

Although the $\mathrm{pH}$ value in this study has no direct effect on consumer health, low $\mathrm{pH}$ value generally increases the dissolution of elemental constituents in rainwater and increase the potential of leaching process when the rainwater in contact with the possible leaching surfaces. Therefore, there is a possibility contamination of nutrients and HMs in rainwater.

Table 3: Comparison rainwater parameter with $\mathrm{MMOH}$ guidelines for drinking water quality

\begin{tabular}{|c|c|c|c|}
\hline \multirow{2}{*}{ Parameter } & \multicolumn{2}{|c|}{ This Study } & \multirow{2}{*}{$($ MMOH, 2010) } \\
\cline { 2 - 3 } & Wet season & Dry season & \multirow{2}{*}{ NA } \\
\hline $\begin{array}{c}\text { Temperature } \\
\left({ }^{\circ} \mathrm{C}\right)\end{array}$ & 25.23 & 25.69 & $6.5-9.0$ \\
\hline $\mathrm{pH}$ & 6.39 & 6.72 & 1000 \\
\hline $\mathrm{TDS}(\mathrm{mg} / \mathrm{L})$ & 3.07 & 7.60 & $\mathrm{NA}$ \\
\hline $\mathrm{EC}(\mathrm{mS} / \mathrm{cm})$ & 0.003 & 0.014 & 200 \\
\hline $\mathrm{Al}(\mu \mathrm{g} / \mathrm{L})$ & 10.97 & 11.29 & 2000 \\
\hline $\mathrm{Cu}(\mu \mathrm{g} / \mathrm{L})$ & 2.73 & 1.22 & 100 \\
\hline $\mathrm{Mn}(\mu \mathrm{g} / \mathrm{L})$ & 1.53 & 3.50 & 3000 \\
\hline $\mathrm{Zn}(\mu \mathrm{g} / \mathrm{L})$ & 14.61 & 10.95 & \\
\hline
\end{tabular}

\subsection{Source Identification of Heavy Metals}

Principal components analysis (PCA) is a variable reduction technique which is very useful to identify the origin of pollutants in rainwater samples. Table 4 shows eigenvalues greater than one and PCA extracts two principal components from spatial rainwater data $(38 \times 4)$ and explain over $75 \%$ of the total variance. The first component (PC1) accounted about $49 \%$ of the total variance and has strong positive loadings on $\mathrm{Cu}(0.84)$ and $\mathrm{Zn}(0.78)$ as seen in Table 4. Dissolved $\mathrm{Cu}$ and $\mathrm{Zn}$ concentrations in rainwater possibly originate from wood industry because of wood preservative and fungi-killing chemical generally use copper sulphate/chloride and zinc sulphate/chloride (14-15). The second component (PC2) accounted about $26 \%$ of the total variance and showed strong positive loading for $\mathrm{Mn}(0.77)$ and $\mathrm{Al}(0.91)$. The presence of $\mathrm{Mn}$ and $\mathrm{Al}$ in rainwater indicating that $\mathrm{PC} 2$ was originated from the natural soil as $\mathrm{Al}$ and $\mathrm{Mn}$ were naturally present in soil (14). The construction activity for residential college development within the sampling site perhaps influenced the $\mathrm{Al}$ and $\mathrm{Mn}$ concentration as well.

Table 4: Principal component analysis of heavy metals. Bold values show a strong positive loading

\begin{tabular}{ccc}
\hline $\mathrm{HMs}$ & $\mathrm{PC} 1$ & $\mathrm{PC} 2$ \\
\hline $\mathrm{Al}$ & 0.45 & $\mathbf{0 . 7 7}$ \\
$\mathrm{Cu}$ & $\mathbf{0 . 8 4}$ & -0.05 \\
$\mathrm{Mn}$ & -0.07 & $\mathbf{0 . 9 1}$ \\
$\mathrm{Zn}$ & $\mathbf{0 . 7 8}$ & 0.27 \\
Initial eigenvalue & 1.95 & 1.06 \\
\% of Variance & 48.80 & 26.42 \\
Cumulative \% & 48.80 & 75.22 \\
Potential source & Wood industry & Natural soils and construction \\
\hline
\end{tabular}

\subsection{Heavy Metals Health Risk Assessment}

The human health risk posed by heavy metals ( $\mathrm{Al}, \mathrm{Cu}, \mathrm{Mn}$ and $\mathrm{Zn}$ ) in the collected rainwater from Jengka, Pahang through water ingestion and dermal contact were evaluated. Results for individual HMs in rainwater from wet and dry seasons showed that the HQ values for adults via ingestion and dermal contact were lower than unity $(\mathrm{HQ}<1)$, indicating that there was no adverse health effect (Table 5). HQ values for adults via ingestion for $\mathrm{Al}, \mathrm{Cu}, \mathrm{Mn}$ and $\mathrm{Zn}$ in wet season were $0.0003,0.0022$ and 0.0024 , while for dry season were $0.0004,0.0010,0.0055$ and 0.0011 , respectively. HQ values of each HMs in both seasons for adults via ingestion decrease in the order of $\mathrm{Mn}>\mathrm{Zn}>\mathrm{Cu}>\mathrm{Al}$. Subsequently, the HQ values for adults via dermal contact for $\mathrm{Al}, \mathrm{Cu}, \mathrm{Mn}$ and $\mathrm{Zn}$ were $0.0026,0.0031,0.0200,0.0058$ for the wet season, while that was $0.0027,0.0035,0.0456$ and 0.0044 for dry season, respectively. HQ values of each HMs in both seasons for adults via dermal contact decrease in the following order: $\mathrm{Mn}>\mathrm{Zn}>\mathrm{Cu}>\mathrm{Al}$. Although the HQ values of the corresponding HM in the respective seasons in this study were lower than one, the results show that the HQ value increase linearly with HMs content in rainwater. Therefore, the presence of HMs in rainwater need to be continuously monitored to ensure the rainwater safety level.

Hazard index (HI) for a corresponding heavy metal and the combined risk for all heavy metals $\left(\sum \mathrm{HI}\right)$ from wet and dry seasons were determined and shown in Table 5. An individual adult that expose to the rainwater in Jengka, Pahang pose a higher risk in the dry season (0.0642) compared to wet season (0.0380). However, the combined hazard risk was lower than unity $\left(\sum \mathrm{HI}<1\right)$, indicating that there were no adverse non-carcinogenic risks for an individual that expose to the rainwater in the study area regardless the seasons.

Table 5: Health risk assessment

\begin{tabular}{|c|c|c|c|c|c|c|c|c|}
\hline HMs & $\begin{array}{c}\text { CDI ingestion } \\
(\mu \mathrm{g} / \mathrm{kg} / \text { day })\end{array}$ & $\begin{array}{l}\text { CDI dermal } \\
(\mu \mathrm{g} / \mathrm{kg} / \text { day })\end{array}$ & $\begin{array}{c}\text { RfD ingestion }^{\mathrm{a}} \\
(\mu \mathrm{g} / \mathrm{kg} / \text { day })\end{array}$ & $\begin{array}{c}\text { RfD dermal }^{\mathrm{b}} \\
(\mu \mathrm{g} / \mathrm{kg} / \text { day })\end{array}$ & HQ ingestion & HQ dermal & $\mathrm{HI}$ & $\sum \mathrm{HI}$ \\
\hline \multicolumn{9}{|c|}{ a) wet season } \\
\hline $\mathrm{Al}$ & 0.3453 & 0.2632 & 1000 & 100 & $3.45 \times 10^{-4}$ & $2.63 \times 10^{-3}$ & $2.98 \times 10^{-3}$ & \multirow[t]{4}{*}{$3.80 \times 10^{-2}$} \\
\hline $\mathrm{Cu}$ & 0.0861 & 0.0370 & 40 & 12 & $2.15 \times 10^{-3}$ & $3.08 \times 10^{-3}$ & $5.23 \times 10^{-3}$ & \\
\hline $\mathrm{Mn}$ & 0.0482 & 0.0367 & 20 & 1.84 & $2.41 \times 10^{-3}$ & $2.00 \times 10^{-2}$ & $2.24 \times 10^{-2}$ & \\
\hline $\mathrm{Zn}$ & 0.4600 & 0.3506 & 300 & 60 & $1.53 \times 10^{-3}$ & $5.84 \times 10^{-3}$ & $7.38 \times 10^{-3}$ & \\
\hline \multicolumn{9}{|c|}{ b) dry season } \\
\hline $\mathrm{Al}$ & 0.3555 & 0.2710 & 1000 & 100 & $3.56 \times 10^{-4}$ & $2.71 \times 10^{-3}$ & $3.07 \times 10^{-3}$ & $6.42 \times 10^{-2}$ \\
\hline
\end{tabular}




\begin{tabular}{|l|l|l|c|c|c|c|c|}
\hline $\mathrm{Cu}$ & 0.0383 & 0.0420 & 40 & 12 & $9.57 \times 10^{-4}$ & $3.50 \times 10^{-3}$ & $4.46 \times 10^{-3}$ \\
\hline $\mathrm{Mn}$ & 0.1101 & 0.0839 & 20 & 1.84 & $5.51 \times 10^{-3}$ & $4.56 \times 10^{-2}$ & $5.11 \times 10^{-2}$ \\
\hline $\mathrm{Zn}$ & 0.3450 & 0.2629 & 300 & 60 & $1.15 \times 10^{-3}$ & $4.38 \times 10^{-3}$ & $5.53 \times 10^{-3}$ \\
\hline
\end{tabular}

\section{Conclusion}

All parameters concentration was lower in wet season compared to those in dry season except $\mathrm{Cu}$ and $\mathrm{Zn}$. In terms of seasonal variation, all parameters except HMs and temperature were significantly different. HMs was originated from the natural soil as well as wood industry and construction activities as discovered by PCA. Human health risk assessment revealed that the HQ and HI values of HMs in rainwater were lower than one and therefore does not pose any health risk to human population. Subsequently, based on drinking water guidelines, all HMs contents in the collected rainwater in Jengka, Pahang were within the recommended values by $\mathrm{MMOH}$. This means the rainwater can be used for a portable use. The results of this study provide insight into health risk assessment and the level of rainwater pollution in Jengka. Nevertheless, further studies on the toxic $\mathrm{HMs}$ such as $\mathrm{Pb}, \mathrm{Cd}$, and $\mathrm{Se}$ are recommended to enhance the knowledge needed to safeguard the rainwater quality level.

\section{Acknowledgement}

We were grateful to the Faculty of Applied Sciences, Universiti Teknologi MARA (Shah Alam and Pahang) for providing all the necessary research facilities and financially supporting this study as well as the Ministry of Higher Education for the support provided via Research Acculturation Grant Scheme (RAGS/2013/UITM/STWN01/1)

\section{References}

[1] Liu X, Song Q, Tang Y, Li W, Xu J, Wu J, et al. Human health risk assessment of heavy metals in soil-vegetable system: A multimedium analysis. Sci Total Environ. 2013;463-464:530-40.

[2] USEPA (United States Environmental Proctection Agency). Risk Assessment Guidance for Superfund Volume I Human Health Evaluation Manual ( Part A ). Vol. I. 1989.

[3] Norberg GF, Fowler BA. Risk Assessment. In: Nordberg GF, Fowler BA, Nordberg M, editors. Handbook on the Toxicology of Metals. Fourth. Academic Press; 2015. p. 461-86.

[4] Ma Y, Egodawatta P, McGree J, Liu A, Goonetilleke A. Human health risk assessment of heavy metals in urban stormwater. Sci Total Environ. 2016;557-558(May):764-72.

[5] Ma Y. Human Health Risk of Toxic Chemical Pollutants Generated From Traffic and Land Use Activiteis. Queensland University of Technology; 2016

[6] Keshavarzi B, Tazarvi Z, Rajabzadeh MA, Najmeddin A. Chemica speciation, human health risk assessment and pollution level of selected heavy metals in urban street dust of Shiraz, Iran. Atmos Environ. 2015;119(August):1-10.

[7] Li P, Lin C, Cheng H, Duan X, Lei K. Contamination and health risks of soil heavy metals around a lead/zinc smelter in southwestern China. Ecotoxicol Environ Saf 2015;113(August):391-9.

[8] Sulaiman FR, Mohd Rafi NF, Kamarudin SNS, Syed Ismail SN Assessment of physicochemical characteristics and health risk of drinking water. J Teknol. 2016 Feb;78(2):107-14.

[9] Odnevall Wallinder I, Verbiest P, He W, Leygraf C. Effects of exposure direction and inclination on the runoff rates of zinc and copper roofs. Corros Sci. 2000 Aug;42(8):1471-87.

[10] Low KH, Koki IB, Juahir H, Azid A, Behkami S, Ikram R, et al. Evaluation of water quality variation in lakes, rivers, and ex-mining ponds in Malaysia (review). Desalin Water Treat. 2016;(June):1-25.

[11] WHO. Guidelines for Drinking Water Quality - 4th ed. 2011.

[12] Sulaiman FR, Mustaffa NFS, Mohd Khazaai SN. Preliminary assessment of selected metals in agricultural soils in Jengka, Pahang, Malaysia. Environ Earth Sci. 2016;75(3):1-9.

[13] Chang M, McBroom MW, Scott Beasley R. Roofing as a source of nonpoint water pollution. J Environ Manage. 2004 Dec;73(4):307-
[14] Mummullage SWN. Source Characterisation of Urban Road Surface Pollutants for Enhanced Water Quality Predictions. Queensland University of Technology; 2015.

[15] MMOH. Drinking Water Quality Surveillance Programme Ministry of Health. Ministry of Health Malaysia. 2010.

[16] Igbinosa IH, Aighewi IT. Quality assessment and public health status of harvested rainwater in a peri-urban community in Edo State of Nigeria. Environ Monit Assess. 2017;189(405).

[17] NHMRC, NRMMC. Australian Drinking Water Guidelines Paper 6 National Water Quality Management Strategy. National Health and Medical Research Council, National Resource Management Ministerial Council, Commonwealth of Australia,. Canberra.; 2011. 